\title{
The Effectiveness of Explicit and Implicit Corrective Feedback on Interlingual and Intralingual Errors: A Case of Error Analysis of Students' Compositions
}

\author{
Mohammad Falhasiri (Corresponding author), \\ Department of English Language, \\ Faculty of Foreign Languages, University of Isfahan, Iran \\ Tel: 98-917-805-2690 E-mail: falhasiri @yahoo.com \\ Dr. Mansoor Tavakoli \\ Department of English Language, \\ Faculty of Foreign Languages, University of Isfahan, Iran \\ Fatemeh Hasiri \\ Department of English Language, \\ Faculty of Foreign Languages, University of Shiraz, Iran \\ Ali Reza Mohammadzadeh \\ Department of English Language, \\ Faculty of Foreign Languages, University of Shiraz, Iran
}

Received: April 1, $2010 \quad$ Accepted: April 21, $2010 \quad$ doi:10.5539/elt.v4n3p251

\begin{abstract}
This study intends to shed light on the most occurring grammatical and lexical (pragmatic) errors which students make in their compositions. For this purpose, 23 male and female undergraduate students from different majors were asked to take part in the present study. Each week, for four weeks, students were asked to write 4 compositions on predetermined topics. Students' writings were analyzed for errors based on a linguistic Category Taxonomy and the frequency of errors for each category was calculated. Two kinds of corrective feedback were devised based on the type of errors observed, deductive (explicit) explanation of interlingual errors and inductive (implicit) clarification of intralingual errors. After the treatment, students wrote four more compositions and the frequencies of errors for the two sets of writings were compared to see if any significant changes had occurred. It was found that the most errors were of interlingual category (71\%). It was also concluded that in 22 out of 26 categoties, the frequency of errors decreased. Deductive (explicit) teaching of interlingual and also inductive (implicit) teaching of intralingual erroneous points decreased the error frequency of students. Moreover, interlingual errors were more affected than intralingual in case of error reduction.
\end{abstract}

Keywords: Interlingual errors, Intralingual errors, Error analyses, Linguistic taxonomy, Deductive, Inductive, Explicit implicit feedback.

\section{Introduction}

Writing is an "intricate" and complex task; it is the "most difficult of the language abilities to acquire" (Allen \& Corder, 1974, p. 177). Writing is a complex process even in the first language. Undoubtedly, it is more complicated to write in a foreign language. Consequently, lots of researchers have intended to identify the common error EFL students' make in writing the second language. Of course, a better understanding of the errors and the origin of such errors in process of EFL writing will help teachers know students' difficulties in learning that language. Moreover, it will aid in the adaptation of appropriate teaching strategies to help learn better.

Many scholars in the field of error analyses have stressed the significance of second language learners' errors. Cored (1967), for instance, in his remarkable article, mentions that "they are significant in three different ways. First, to teachers, in that they show how far towards the goal the learner has progressed. Second, they provide to the researcher evidence of how a language is acquired, what strategies the learner is employing in his learning of a language. Thirdly, they are indisputable to the learner himself because we can regard making of errors as a device 
the learner uses in order to learn" (p. 161). Researchers are interested in errors because they are believed to contain valuable information on the strategies that people use to acquire a language (Richards, 1974; Taylor, 1975; Dulay and Burt, 1974). Moreover, according to Richards and Sampson (1974, p. 15), "At the level of pragmatic classroom experience, error analysis will continue to provide a method by which the teacher assesses learning and teaching and determines priorities for future effort."'(Khudabande 2006).

Brown 2007 states that there have been two schools of thought in respect to learner's errors. The behaviorist school, for which the occurrence of errors should be avoided, otherwise they would become a bad habit for the learner. With this view, contrastive analysis of the native and the target language became an important aspect of studying the language differences. Contrary to this view, the cognitivist school believes that in spite of the teacher's efforts, the errors will occur, and it does not necessarily mean the learner's failure, rather progress the learner is making in the language learning system. With this view, the cognitivist has placed an emphasis on hypothesis formation, experiments and feedback, raising the issue of error analysis as a way to study the difficulties encountered by the second language learner.

Between the two production skills, writing is the more intriguing one because in spoken conversations, we make sense of the dialogue in a complex back-and-forth process of negotiation of meaning between speakers. In written texts; however, this back-and-forth of negotiation is not possible. Because there is no possibility of negotiating meaning of written documents, the inevitable problems of misunderstandings are exacerbated" (Penman, 1998). Hence, we can say that writing is an "intricate" and complex task; it is the "most difficult of the language abilities to acquire" (Allen \& Corder, 1974, p. 177).

Corder $(1967,1971)$ and James (1998) revealed a criterion that elucidates the difference between error and mistake and it is the self-correctability criterion. A mistake can be self-corrected, but an error cannot. Errors are "systematic," i.e. likely to occur repeatedly and not recognized by the learner. Hence, only the teacher or researcher would locate them, the learner wouldn't (Gass \& Selinker, 1994).

Due to the fact that there is not a clear cut answer to dealing with students' writing errors, this study can be of a help to teachers to diagnose the most problematic areas for students and if explanation of those errors can help decrease error frequency. Error analysis the best tool for describing and explaining errors made by speakers of other languages (Johanson, 1975) this one is conducted in order to know the sources of these errors and the reasons behind their continued occurrence.

\section{Background on error analysis}

Ellis (1994: 18) identifies four essential areas of SLA investigation: 1) characteristics of learner language, which involve errors, acquisition orders, variability, and pragmatic features; 2) learner-external factors, where social contexts are concerned; 3) learner-internal mechanisms, which deal with first language transfer, learning processes, communication strategies, and knowledge of linguistic universals; and 4) the language learner, where motivation and learner strategies are investigated. Among these four areas of study, the description of the characteristics of learner language is considered the most essential. Without describing the learner's language in detail, we cannot adequately explain what occurs in the acquisition process. In other words, we cannot investigate how learners' internal or external factors affect the learner's language until we have profound understanding of the general characteristics of the learner's language itself. (Harishima, 2006)

Harishima (2006) states that in order to further understand the nature of learner language, error analysis (EA) has widely been used among SLA researchers since it took over its predecessor, contrastive analysis, in the late 1960s. EA begins with the premise that errors can be attributed to a variety of factors, not solely to interference from the native language. By collecting a raw linguistic sample and analyzing the errors within it, researchers in the EA closely examine, and hopefully explain, the linguistic competence of a second language learner.

Error analysis (EA) emphasizes "the significance of errors in learners' interlanguage system" (Brown, 1994, p. 204). The term interlanguage, introduced by Selinker (1972), refers to the systematic knowledge of an L2 which is independent of both the learner's L1 and the target language. Nemser (1971) referred to it as the Approximate System, and Corder (1967) as the Idiosyncratic Dialect or Transitional Competence. Error analysis is a type of linguistic analysis that focuses on the errors learners make. It consists of a comparison between the errors made in the Target Language (TL) and that TL itself.

Abisamra (2003) and khudabandeh (2006) in their articles on error analyses report that researchers are interested in errors because they are believed to contain valuable information on the strategies that people use to acquire a language (Taylor, 1975; Dulay \& Burt, 1974). Moreover, according to Richards (1974), "At the level of pragmatic classroom experience, error analysis will continue to provide one means by which the teacher assesses 
learning and teaching and determines priorities for future effort". According to Corder (1974), error analysis has two objects: one theoretical and another applied. The theoretical object serves to "elucidate what and how a learner learns when he studies a second language." And the applied object serves to enable the learner "to learn more efficiently by exploiting our knowledge of his dialect for pedagogical purposes."

Therefore, EA can be considered as a fundamental tool in language teaching in order to recognize teacher's point of view and readdress one's methodology for fixing and fulfilling the students' gaps (Londono Vasquez, 2007). In other words, as Cored (1967) defined, EA is a procedure used by both researchers and teachers which involves collecting samples of learner language, identifying the errors in the samples, describing these errors, classifying them according to their nature and causes, and evaluating their seriousness. The purpose of Error Analysis is, in fact, to find "what the learner knows and does not know' and to "ultimately enable the teacher to supply him not just with the information that his hypotheses is wrong, but also, importantly, with the right sort for information or data to form a more adequate concept of a rule in the target language" (Cored, 1974, P.170). The investigation of errors can be at the same time diagnostic and prognostic. It is diagnostic because it can tell us the learner's state of the language (Corder, 1967) at a given point during the learning process and prognostic because it can tell course organizers to reorient language learning materials on the basis of the learners' current problems.

Corder (1967 \& 1974) identified a model for error analysis which included three stages:

1). Data collection: Recognition of idiosyncrasy

2). Description: Accounting for idiosyncratic dialect

3). Explanation (the ultimate object of error analysis).

Ellis (1997, pp. 15-20) and Hubbard et al. (1996, pp. 135-141) elaborate on previous EA models by Corder (1967 \& 1974) as follow: The initial step requires the selection of a corpus of language followed by the identification of errors. The errors are then classified. The next step, after giving a grammatical analysis of each error, demands an explanation of different types of errors.

In 1994, Gass \& Selinker introduced an error analysis model with the following steps: data selection, Identification of errors, Classification of errors, Quantification of errors, Analyses of the source of error, and Remediation for errors.

According to Dulay \& Burt (1974), there are four types of "goofs":

1). Interference-like goofs

2). L1 Developmental goofs

3). Ambiguous goofs (either interference-like or L1 developmental goofs)

4). Unique goofs (neither interference-like nor L1 developmental goofs)

\subsection{Error Taxonomies}

Richards (1971), in his study, showed the different types of errors relating to production and distribution of verb groups, prepositions, articles, and the use of questions, based on which, he distinguished three sources of errors:

Interference errors: errors resulting from the use of elements from one language while speaking/writing another.

Intralingual errors: errors reflecting general characteristic of the rule learning such as faulty generalization, incomplete application of the rules and failure to learn conditions under which rules apply, and

Developmental errors: errors occurring when learners attempt to build up hypothesis about the target language on the basis of limited experiences.

According to Richards (1971), intralingual errors are also divided into the following categories:

Overgeneralization errors: the learner creates a deviant structure on the basis of other structures in the target language (e.g. "He can sings" where English allows "He can sing" and "He sings".

Ignorance of rule restrictions: the learner applies rules to context where they are not applicable (e.g. "He made me to stay")

Incomplete application of rules: the learner fails to use a fully developed structure (e.g. "you like to sing" in place of "do you like to sing").

False hypothesis: the learners do not fully understand a distinction in the target language (e.g. the use of "was" as a marker of past tense in "one day it was happened").

However, as Schacheter and Celce-Murcia (1977) pointed out, the distinction between intralingual and 
developmental errors is rather fuzzy in their term. As a result, Richards (1974) classified errors into two categories:

Interlingual errors: These errors are caused by mother tongue interference.

Intralingual and developmental errors: this kind of errors occurs during the learning process of the second language learning at a stage when the learners have not really acquired the knowledge.

Burt and Kiparsky developed a linguistic category taxonomy into which they classified several English errors made by students learning English as well as host environments. (see table $1 \& 2$ ).

\section{Literature review}

Firstly, some articles done on feedback will be reviewed and afterwards, the result of some articles which discussed the effect of different kinds of error feedback will be presented.

In spite of the fact that myriad numbers of articles have been written on error correction and feedback for L2 learners, the controversies still remain and there is no clear cut answer. There are some studies which have considered the influence of error feedback; however, the findings are conflicting. (Fathman \& Whalley, 1990; Kepner, 1991; Polio, Fleck, \& Leder, 1998; Semke, 1984). Most studies on error correction in L2 writing classes have provided evidence that students who receive error feedback from teachers improve in accuracy over time (Chandler, 2000; Ferris, 1995a, 1997; Ferris et al., 2000; Frantzen, 1995; Lalande, 1982; Robb, Ross, \& Shortreed, 1986; Sheppard, 1992).

Abisamra (2003) in her error analyses study of Arab English learners found that $35.9 \%$ of errors were of transfer/Interlingual errors while,64.1\% were developmental/Intralingual. She found that the highest percentage of transfer errors was in semantics \& lexis, and as for the highest percentage of developmental errors, it was, by far, in substance (mainly spelling). Other studies by George (1972), Lance (1969), Richards (1971), and Brudhiprabha (1972) also found that only one-third of the second language learners' errors can be attributed to native language transfer.

Ferris and Roberts (2001) considered the extent to which error feedback needs to be explicit so that students get to self edit their texts. They state that their findings are in line with Krashen's (1982) Monitor Hypothesis, which claims that formal learning and explicit knowledge function as an editor which operates when learners are intentionally focused on form, when they know the rule involved, and when they have sufficient time to reckon upon and apply their knowledge. In their study, the feedback group outperformed the no-feedback group in editing outcomes; nonetheless, coded feedback had no noticeable effect. They were not the only researchers concerning themselves with this issue, in second language acquisition, the main body of research has been very much in response to Krashen's claim that learners only learn through unconscious acquisition. Learning, he claims, which is conscious, does not lead to acquisition, which is unconscious, and acts only as a monitor. Conversely, some other researchers (Ellis, 1991; Schmidt, 1990, 1994, 2001; Schmidt and Frota, 1986) believe that learners'attention to forms is necessary for earners. Ashwell (2000), Fathman and Whalley (1990), and Ferris and Roberts (2001) did a correction/ no correction comparison and all three studies showed significant effects for the correction groups. With a similar design, Ashwell (2000) obtained similar results: All groups receiving feedback made gains in formal accuracy. Ferris and Roberts (2001) provided evidence of remarkable positive effects for feedback groups versus the non-feedback group, although the non-feedback group was more successful than the others in correcting lexical errors (word choice).

Danielle Gue'nette (2007) in a recent article reviewed the treatments which varied between combining feedback on form and feedback on content and experimenting with different types of feedback on form. In 1996 Truscott wrote a review article believing that all forms of error correction of L2 student writing are not only ineffective but potentially negative and should be abandoned. Truscott $(1996,1999,2007)$ took the position that the revision research had no implications for the issue he was addressing, because the point of his "case against grammar correction" was that correction is not useful as a teaching device, while the revision research was about its usefulness specifically as an editing tool, a way to improve a particular manuscript. (Cited from John Truscott and Yi-ping Hsu, 2008)

Truscott (1996) criticizes the error correction practice due to the fact it treats different linguistic categories (lexical, syntactic, and morphological) as being equivalent, when in fact they represent separate domains of knowledge that are acquired through different stages and processes (Ferris and Roberts 2001). However in this study, these categories are dealt with separately because previous studies of error correction show that when specific categories of written error were targeted for feedback and analysis, there were significantly different rates of student achievement and progress across error types (Chaney, 1999; Ferris, 1995a; Ferris et al., 2000; Ferris \& Helt, 2000; Frantzen \& Rissell, 1987; Lalande, 1982; Sheppard, 1992). 
Most surveys of student preferences show that students are particularly positive about receiving feedback on language issues, although they also want teachers to comment on content and ideas of their writing (Hedgcock \& Lefkowitz, 1994; Leki, 1991; Oladejo, 1993; Saito, 1994; Ferris, 1995b; Truscott, 1996; Rennie, 2000). As L2 students place a high premium on accuracy in writing, they are eager to have all their errors pointed out by the teacher (Komura, 1999; Lee, 2005; Leki, 1991; Rennie, 2000). While studies by Radecki and Swales (1988) and Lee (2005) show that students wanted overt correction of errors (i.e., direct error feedback) from teachers, most of the other studies (e.g., Arndt, 1993; Hyland, 2001; Saito, 1994) suggest that students preferred indirect to direct error feedback, where they were given clues and also a more active role to play in the feedback process. More advanced students like the L2 graduate students in Leki's (2006) and Riazi's (1997) studies, for example, particularly valued teacher feedback as a useful means to help them develop disciplinary literacy. (Cited from Lee, 2008)

The bulk of studies have compared the effect of different types of corrective feedback. Error correction researchers who have examined the effects of two contrasting types of feedback i.e. direct (when the teacher provides the correct form) (Bitchener, Young, \& Cameron, 2005; Ferris, 2003). and indirect (when the teacher indicates the error but does not provide the correct form) (Ferris \& Roberts, 2001; Robb, Ross, \& Shortreed, 1986) have reported that indirect feedback helps students to make progress in accuracy over time more than direct feedback does (Ferris et al., 2000; Ferris \& Helt, 2000; Lalande, 1982) or at least equally as well (Frantzen, 1995; Robb et al., 1986). For an instance, Ferris (2002) reported that direct error correction led to more correct revisions (88\%) than indirect error feedback $(77 \%)$. Over the course of the semester, however, it was noted that students who received indirect feedback reduced their error frequency ratios substantially more than those who received direct feedback.

Ferris and Roberts (2001) examined the effects of three different feedback treatments (errors marked with codes; errors underlined but not otherwise marked or labeled; no error feedback) and found that both error feedback groups significantly outperformed the no feedback control group, however they found that there were no significant differences between the group given coded feedback and the group not given coded feedback.

Ferris (2002) suggests that indirect feedback is generally more appropriate and effective than direct feedback. The danger of direct feedback is that teachers may misinterpret students' meaning and put words into their mouths. Direct feedback is appropriate (see Ferris, 2002), however, (1) for beginner students; (2) when errors are 'untreatable', i.e., errors not amenable to self-correction such as sentence structure and word choice and (3) when teachers want to draw students' attention to other error patterns which require student correction (Lee 2003). Leki (1991) and Roberts (1999) have also pointed out that students sometimes feel that indirect feedback does not provide them with sufficient information to resolve more complex errors such as idiosyncratic and syntactic errors. Chandler (2003) explained that a greater cognitive effort is expended when students are required to use indirect feedback to make their own corrections is offset by the additional delay in knowing whether their own hypothesized correction is in fact correct. (For more see Bitchener 2009).

In Carroll and Swain (1993) and Carroll (2001), direct metalinguistic feedback outperformed all other types of correction. Formal grammatical explanation was more effective than meaning-focused debriefing in Muranoi (2000) study. Some classroom research studies, conducted by Doughty (1991), Leow (1998), and Scott $(1989,1990)$ have also shown that explicit correction is more beneficial than implicit correction.

Dabagh (2005) also found that explicit correction on the whole is more effective than implicit correction with one caveat; that is, explicit correction seems to work very well for morphological and not so well for syntactical features.

Chandler (2003) found that if students were required to correct their errors their accuracy improves without a decline in fluency over the semester, as measured by self-reports of time students spent writing the same amount and kind of text. The researcher states that if students did not revise their writing based on feedback about errors and only had teachers mark errors was equivalent to giving no error feedback since the students' new writing did not increase in correctness over one semester.

John Bitchener \& Knoch state that the simple provision of error correction is just as effective as the additional provision of written and oral meta-linguistic explanation. Similar findings were also reported in Bitchener (2008) and Bitchener and Knoch (2008). Direct error correction alone may be as effective as direct error corrective with written meta-linguistic explanation or direct error corrective with both written and spoken meta-linguistic explanation and that the level of increased accuracy in the immediate post-test (clear evidence of the effect of written corrective feedback on improved accuracy) was retained over a two month period. The significant role of direct written corrective feedback on students' linguistic error is supported by other studies (Bitchener, 2008; Bitchener and Knoch, 2008; Sheen, 2007) that have reported on the short-term effectiveness of written corrective feedback.

The finding of this study will add to a growing body of research that has investigated the effect of different feedback 
strategies on accuracy performance. For instance, it has already been noted that indirect feedback is more effective than direct feedback in helping learners improve the accuracy of their writing. Because little research has specifically investigated the effect of oral direct feedback on improved accuracy, the findings of the present study are noteworthy.

\section{Research questions and hypotheses}

This study tries to shed light on the most frequent errors students make in their writings and the effect of feedback on decreasing the error frequency. As so, this study is an effort to answer the following questions:

Q1. Does inductive explanation (implicit feedback) of intralingual errors students make in their writings decreases errors?

Q2. Does deductive explanation (explicit feedback) of interlingual errors students make in their writing decreases errors?

To answer the above questions the following null hypothesis were tested.

H01: Inductive explanation of intralingual errors does not have any influence on error frequency.

H02: Deductive explanation of interlingual errors does not have any influence on error frequency.

\section{Method}

\subsection{Participants}

23 low-intermediate leveled students who had enrolled in English classes at University of Isfahan in spring 2009 participated in this study. The class was composed of 16 girls and 7 boys aged 19 to 25 . They were pre tested on Oxford Placement test to make sure that the participants were homogeneous. Participants' majors were different and the class was not a prerequisite course of university. The sessions were held 2 days a week for 50 days.

\subsection{Materials and procedure}

Students were supposed to finish 6 units of the "Cutting Edge" series book which is a multi skilled course book. They were asked to write a composition of 180 words on a predetermined topic every other session. 80 writings (roughly 13000 words) were submitted by the end of the forth week. Students' compositions were analyzed for errors based on EA taxonomy by M. Burt and C. Kiparsky (1972) and errors were assigned to different linguistic categories and error types. The frequency of each error type was calculated. No argument is being made here that this error categorization system is better or worse than other possible ones. It is chosen because it is more exhaustive than most of other taxonomies; for example, Ferris and Roberts (2001) which used only five categories. Then, different teaching methodologies were devised based on the fact that whether the errors were interlingual or intralingual. (For points where it was difficult to determine if the error was interlingual or intralingual, the student was interview). For interlingual errors, Oral meta-linguistic explanation took the form of a 45-minute mini-lesson. During this session, the researcher explained the rules and example of all the errors students made. Additional examples were illustrated on the whiteboard and discussed with the class. The structural difference between L1 and L2 was discussed in students' mother tongue. As an instance the teacher compared the use of preposition in Farsi and English for a similar verb. For intralingual errors the teacher again exposed students to the error and then inductively started to teach the grammar point in the target language. The teaching of errors took two "forty five" minutes of two sessions in a row. Explicit correction involved metalinguistic feedback as well as the provision of the correct forms, but implicit correction involved only provision of the correct form.

Later, students were required to write 4 more compositions of 180 words on topics that the teacher had assigned. The 80 writings were analyzed and the frequencies of errors were calculated to see if any significant changes in students' number of mistakes had occurred. In order to ensure the reliability of the scoring, $20 \%$ of the writings were graded a second time, 3 months later, by the same scorer. The intra-rater correlation for the two markings of the same narrative was .967 , with S.D $=.066$.

\section{Presentation of data:}

The data are presented in two head categories, interlingual and intralingual. Interlingual errors are in turn divided into ten subcategories and intralinguals into 16 categories. The categories were taken from M. Burt and C. Kiparsky (1972) taxonomy. In front of each category two numbers are mentioned, the first of which is the number of errors for the first four writing prior to the treatment, and the second refers to the number of errors after the treatment. All the examples mentioned bellow, are erroneous. 
6.1 Interlingual Errors: When students do not know the appropriate word, structure or expression to use, they resort to their first language. All these errors root from the first language transfer. Students literally translated the intended utterance from Persian. The following sentences might be meaningless to non native Persian speakers, while to Persian speakers they make sense, due to the fact that they are reflecting Persian structure. Not all errors are included due to space limit.

\subsubsection{Misuse of preposition (in general) (25) (10)}

1). Everyone sees the world with a new and so various questions appear for him. 2. It helps him to confront with his problems. 3. Beggars come in our way and want from us money. 4. If people don't help to beggars, they become fewer. 5. All of people in some conditions need to money. 6. My teacher insulted to me. 7. I am content from my life. 8. If you have interest to study, go and study. 9. Permit to me to start my writing with this. 10. They don't have any recreation to enjoy from it. 11. They attend in their class with strong morale. 12. Fathers help to children to achieve better things. 13. Don't judge about people's life14. It is a fact; help to others is a good work.15. Society include of men and women. 16. We shouldn't use from our times and facilities goodly. 17. It is a duty of a country to search about them. 18. It helps him to confront with his problems.

\subsubsection{Using double subject in relative clauses (11) (6)}

1). One thing that the child never thinks about it is money. 2. They elect acts and relationships that they are useful for them. 3. I prefer to help who I know them. 4. Parents are the first persons that a baby knows them. 5. I believe that we have many unreasonable needs that we can omit them. 6. It is a feature that God has given it to us. 7. A mother that born a child is loves her child and for father is too. 8 . All of students in this class are deserve for mark 20. 9. In ancient time people was thought the heart is source of emotion of love.

\subsubsection{Farsi structure with English lexicon (45) (27)}

1). That class suffer all students and depress all of them. 2. You can buy the proof of Iranian university and even Oxford (who is to who) 3. In our country we have friendship apparently. 4. In many cases say is their say without any reason. 5. They do false works in front of their children. 6. I eat dinner external home, in the restaurant. 7. Sometimes a child may treat as an adult or an adult may think treat or do like a child. 8. They should try to arrive to high climax of science. 9. When holiday is too long we stop in now place. 10. Piano gives calm. 11. A child hasn't any worry about anything. 12. I think a child az well az adult enjoy life because nobody don't have expectation from a child. 13. Others think there is a special age for to be an adult, for example age of 18 and 19.14. In many years ago, Iran was a great country. 15. They are relax when they have a some money to save. 16. I am agree with this topic. 17. I wanna write about a movie with name: sixth sense. 18. My dream house is like a palace, maybe a palace like that Sepidbarfi was borned in that or Sinderella was entered that. 19. It has a direct communication to our creation. 20. When snow the boss of school order to holiday, it is laughing reason for holiday. 21. Teachers increase their expectations and set students in pressure with their wantings. 22. Everything is ruined from basis in Iran. 23. In this condition students cannot work and the best work is to leave the country. 24. Parents comprehend their child better than others. 25. I don't like to help people who decay themselves and society. 26. You devote other people other people to reach to your requests.

6.1.4. Misplacing adverbs of frequency in case of modal verbs (5) (1)

1). Their time always is free.

6.1.5. Adjectives used after noun (2) (0)

1). In aspect physical it change. 2. Like car sporty.

6.1.6. Omission of dummy "it" (5) (6)

1. For some people like me is necessary to save some money. 2. When rest create a calm feel is good.

6. 1.7. Omission of personal pronoun (9) (6)

1). They hope their child will be successful in life. 2. We never learn lessons well. 3. They use properties of parents.

6.1.8. Omission of subjects (18) (12)

1). Parents know their child completely for example know what is her behavior. 2. In these situations their responsibility increase and must care about their spouse and children. 3. If ask from me what mark give to appearance I say seven. 4. The nature of human is that want have more. 5. They promise that stay with together always.

\subsubsection{Double negative (5) (2)}

1). They earn money without no trying. 2. I get it that no one can't understand me. 3. No body don't have expectation 
from a child.

6.1.10. Misuse of reciprocal verbs (2) (3)

Parents learn us every things we need for our future.

6.2. Intra lingual errors

6.2.1. Addition of "The" (14) (17)

1). I think the family have a wide influence on their children. 2. Parents are the most effective persons in a child's life. 3. They ridicule the others.

6.2.2Use of wrong tense (14) (16)

They don't grow up yet.

6.2.3. A for An (6) (1)

A electricity

6.2.4. Disagreement of subject and number (21) (15)

1). We have a professor that all of the sessions are speaking about diversity of animals. 2). I think both of them is important.

6.2.5. Failure to attach $3^{\text {rd }}$ person "s" (39) (30) and plural "s" (71) (63)

1). When responsibility increase students can't perform good. 2). World advance rapidly. 3). Our body need it. 4). He want to get it. 5). Ha had no friend.

6.2.6. Omitting "to" (13) (11)

1). I want my money bring me joy. 2). They want collect their money. 3). He likes improve himself. We say ourselves...

6.2.7. Misusing adverbs of quantity (6) (6)

1). In Iran we have much holidays. 2). I have few time. 3). We must learn many of information in lower time. 4). School holiday in our country is to long for this, many time of education waste for this holidays.

6.2.8. Misusing parts of speech (34) (29)

1). I had a bad sick. 2). They ridicule with great enjoy. 3). We should use our time goodly. 4). There is no science reason for that. 5). We should put aside lazy. 6). Industry country

6.2.9. Omission of articles (52) (48)

It is near university.

6.2.10. Omitting to be verb (12) (8)

1). They not satisfied with life. 2). Parents always cannot best teachers. They coming to his class.

6.2.11. Use of to be verb + simple form of verb (6) (4)

1). Mother is loves her child more that others. 2). What is she likes. 3. When knowledge is move, then aims change.

6.2.12. To before object (5) (7)

They want to the best things for their child

6.2.13. Use of do and does before main verb (3) (0)

A person who does beg lower his personality.

6.2.14. Use of relative pronoun that for who (8) (3)

$\mathrm{He}$ is the man that always break his promise.

6.2.15. Another for other (8) (7)

I like to help to anothers.

6.2.16. Irregular plurals (12) (9)

They have many works to do

\section{Result}

The frequency errors in each category for the four writings that were submitted was calculated and the same was 
done to the next four compositions which were submitted after the treatment. Then the Chi square was run to see if the difference is significant. Table 1 displays the categories of interlingual errors and table 2 shows the category of interlingual errors.

The frequency of interlingual errors decreased from 127 to 73 after the provision of explicit feed beck. As indicated in table 1, the percentage of Farsi structure with English lexicon is the highest with 35.4 percent $(\mathrm{f}=45)$ in the first drafts. In the second drafts; however, and after implicit feedback of error, the frequency decreased to $\mathrm{f}=27$. Misuse of prepositions decreased from $19.6 \%(\mathrm{f}=25)$ to $13.7 \%(\mathrm{f}=6)$. The use of double subject in relative clauses differed $(\mathrm{f}=$ 11) to $(\mathrm{f}=6)$. Misplacing the adverbs of frequency decreased from $(\mathrm{f}=5)$ to $(\mathrm{f}=1)$. Student had more errors in the second drafts for "omission of dummy it" ( $\mathrm{f}=5)$ to $(\mathrm{f}=6)$ and "misuse of reciprocal verbs from $(\mathrm{f}=2)$ to $(\mathrm{f}=3)$. Other categories which also decreased include "double negative from $(\mathrm{f}=5)$ to $(\mathrm{f}=2)$, "omission of subject from ( $\mathrm{f}=18)$ to $(\mathrm{f}=12)$, "use of adjective after noun from $(\mathrm{f}=2)$ to $(\mathrm{f}=0)$.

Table 2 suggests that despite implicit feedback the number of errors in two categories increased: Addition of article "the" from ( $\mathrm{f}=14)$ to $(\mathrm{f}=17)$ and use of wrong tense from $(\mathrm{f}=14)$ to $(\mathrm{f}=16)$. This increase is showing that they are less treatable categories and are more difficult to internalize and require more time.

The other categories as shown in table 2, decreased after the teacher corrected students implicitly. It can be inferred from the two tables that both corrective feedbacks are influential to help students be more accurate; nevertheless, some categories are influenced more than the others. This issue will be discussed in detail in conclusion section. When Chi score analysis was run, three of categories of interlingual errors including, "misuse of preposition" Sig (.o11), "Farsi structure with Persian lexicon" Sig (.034) and "Misplacing adverbs of frequency in case of modal verbs" Sig (.000) showed a significant change while none of the categories in intralingual errors had a significant change.

\section{Conclusion and implications:}

As the analyses of students suggest both in the first and second drafts the percentage of intralingual errors was higher. (Before treatment $71.84 \%$ intralingual $28.15 \%$ interlingual and after $78 \%$ intralingual $22 \%$ interlingual). Therefore more than 70 percent of all errors do not root from the interference of mother tongue. Moreover the treatment was less effective for intralingual than for interlingual errors. (Intralingual errors decrease by only 8 percent while interlingual errors by $27 \%$ ).

For interlingual errors, based on the data, "students' misuse of prepositions" "Farsi structure with English lexicon" and "subject omission" after the treatment, i.e. inductive and contrastively explanation of erroneous point in mother tongue, decreased significantly, showing that students awareness of the differences helped reduction of errors and also the fact that students became more mindful of the differences in structures of the two languages. The explicit correction of learners' errors may have triggered the learners' noticing of gaps between the target form and their existing interlanguage forms and this led them to restructure their interlanguage. Moreover, as rod Ellis (1991) claims, in order for acquisition to take place, learners must notice, compare, and integrate the feedback. Therefore, the explicit explanation and feedback may not only have helped the learners to notice the target structure, but also may have led them to compare the target feature with their own interlanguage rules and thereby were able to incorporate it into their interlanguage.

On the other hand, implicit correction probably did not trigger noticing to the same extent as the explicit correction did, and consequently may not have created a situation in which the learners could compare the target forms with their existing interlanguage forms in order to internalize them into their interlanguage systems. Dabagh (2005) also discovered that explicit error feedback was more effective in raising awareness of corrected feature in learners and the number of errors decreased comparing to the group who received implicit feedback. Considering the crucial role of attention in learning (Doughty, 2001; Schmidt, 2001), awareness may have been the main cause for the better performance of the explicit correction group over the implicit.

Explicit feedback involves meta-discourse, whereas implicit feedback may not be perceived as corrective. Dabagh and Basturkmen (2005) in their article mention a number of reasons for the better impact of explicit feedback comparing with implicit: (1) explicit correction created more attention, (2) the fact that learners were explicitly corrected on their errors created a contrast with the form in their interlanguage, (3) the provision of the correct form in implicit correction may not have been effective because it was less clear to learners what was wrong with their erroneous utterances and without such understanding, hypothesis revision was not possible, and (4) learners most likely perceived the explicit corrections as corrective feedback requiring them to correct their errors whereas this was not the case with the implicit feedback. 
For interlingual errors it is important to mention the error in a contrastive mode, so that students reckon upon he potential differences between the mother tongue and target language (TL).

"Using double subject in relative clauses" and "Omission of personal pronoun" categories" errors which were due to literal translation of the intermediate students also decreased, showing that students could distinguish the structural difference between English and Farsi; despite the fact that the treatment lasted a total of 90 minutes without any exercises or assignments. Consequently, it can be concluded that errors which are due to the first language interference, can be shunned by a brief explanation and contrastively comparison of the erroneous points.

Intralingual errors, although in a slightly less degree than Interlinguals, also decreased after the treatment, i.e. implicit feed back of the erroneous point in target language.

"Addition of "The"' and "Use of wrong tense" categories' errors on the other hand decreased, substantiating the issue that these errors require a more complex explanation and more exercises due to their complexity and abstractness. It also shows that these to linguistic categories should be taught in a longer period of time and are less treatable.

As a general conclusion, it can be inferred from the experiment that, errors of students compositions should be consulted to the whole class since a brief explanation of the erroneous point can significantly decrease the number of errors. The explanation can differ based on the nature of error.

Truscott's review of studies by Kepner (1991), Semke (1984), and Sheppard (1992) revealed that error correction does not have a significant effect on improving L2 student writing. In contrast, the present study found that the feedback had a significant effect on the participants' accuracy.The provision of full, explicit oral feedback, resulted in greater accuracy comparing to the first script. (see table $1 \& 2$.)

The findings are also in line with that of Bitchener (2008) who found that oral meta-linguistic explanation in the form of a clearly focused mini-lesson (30 minutes) may be as effective as the more time-consuming one-on-one conferences that were included as the oral meta-linguistic explanation in Bitchener et al. (2005). This finding is also supported by a recent SLA study (Ellis et al., 2006) of the effectiveness of oral corrective feedback.

Due to the fact that this study has shown that a single feedback session can be effective in developing accuracy in the use of some linguistic feature (Table $1 \& 2$ ), it is believed that if teachers are able to provide additional feedback on more occasions, it may increase the accuracy rate and reduce the amount of time that is required to achieve a high level of mastery. Therefore, in similar contexts, busy teachers should not necessarily feel that they need to go beyond this approach.

Teachers should be aware that the type of error that needs correction also plays an essential role in the effectiveness of explicit and implicit correction. The evidence from this study indicates that explicit metalinguistic feedback works better with some categories and interlanguage errors better that the others. Hence, teachers need to be selective in deciding which type of error correction to employ, taking into account the category of error.

Teachers need to be aware that corrective feedback tends to be effective with some linguistic features comparing with others. As the result of corrective feedback learners may be able to understand the correct structure of some of their errors but not others and the teacher should not necessarily expect error correction to be uniformly successful. They must keep in mind that EC is sometimes effective and sometimes not. Dabagh (2005) contents that one reason can be the linguistic difficulty of the feature. If the feature is beyond the learners' current developmental stage, the corrective feedback is unlikely to work.

\section{Reference}

Abisamra, N. (2003). An Analysis of Errors in Arabic Speakers' English Writings From http://abisamra03.tripod.com/nada/languageacq-erroranalysis.html

Arndt, V. (1993). Response to writing: Using feedback to inform the writing process. In M. Brook \& L. Walters (Eds.), Teaching composition around the Pacific rim: Politics and pedagogy (pp. 90-116). Clevedon, UK: Multilingual Matters.

Ashwell, T. (2000). Patterns of teacher response to student writing in a multiple-draft composition classroom: Is content feedback followed by form feedback the best method? Journal of Second Language Writing, 9(3), 227-257.

Bitchener, J. Young, S. Cameron, D. (2005). The effect of different types of corrective feedback on ESL student writing. Journal of Second Language Writing. 14, 191-205.

Bitchener, J. Knoch, U. (2009). The relative effectiveness of different types of direct written corrective feedback. System, (37), 322-329. 
Brown, H. D. (1994). Teaching by principles: interactive language teaching methodology. New York: Prentice Hall Regents.

Brudhiprabha, P. (1972). Error analysis: a psycholinguistic study of Thai English compositions. Thesis (M.A.)--McGill University

Carroll, S., Swain, M., 1993. Explicit and implicit negative feedback: an empirical study of the learning of linguistic generalizations. Studies in Second Language Acquisition, 15, 357-366.

Carroll, S., 2001. Input and Evidence. The Raw Material Of Second Language Acquisition. John Benjamins, Amsterdam.

Chandler, J. (2000, March). The efficacy of error correction for improvement in the accuracy of L2 student writing. Paper presented at the AAAL Conference, Vancouver, BC.

Chandler, J. (2003). The efficacy of various kinds of error feedback for improvement in the accuracy and fluency of L2 student writing. Journal of Second Language Writing, 12, 267-296.

Chaney, S. (1999). The effect of error types on error correction and revision. Master's thesis, California State University, Sacramento.

Corder, S. P. (1967). The significance of learners' errors. IRAL, 5, 161-170.

Corder, S. P. (1971). Idiosyncratic dialects and error analysis. IRAL, 9 (2), 147-160.

Crystal, D. (1992). An encyclopedic dictionary of language and languages. Oxford: Blackwell Publishers.

Dabaghi, A \& Basturkmen, H. (2009). The effectiveness of implicit and explicit error correction on learners' performance. System 37, 82-98.

Dulay, H. C. \& Burt, M. (1974). You can't learn without goofing: an analysis of children' second language errors. In J. C. Richards (Ed.), Error analysis (pp. 95-123). London: Longman.

Ellis, R., 1991. Grammaticality judgements and second language acquisition. Studies in Second Language Acquisition, 13, 161-186.

Ellis, R. (1994). The Study of Second Language Acquisition. Oxford: Oxford University Press.

Fallahi, M. (1991). Contrastive linguistics and analysis of errors, Vol. 1: The grammatical structure of English and Persian. Tehran: Iran University Press.

Fathman, A., \& Whalley, E. (1990). Teacher response to student writing: Focus on form versus content. In B. Kroll (Ed.), Second language writing: Research insights for the classroom ( pp. 178- 190). Cambridge: Cambridge University Press.

Ferris, D. R. (1995a). Can advanced ESL students be taught to correct their most serious and frequent errors, CATESOL Journal, 8 (1), 41- 62.

Ferris, D. R. (1997). The influence of teacher commentary on student revision. TESOL Quarterly, 31, 315- 339.

Ferris, D. R., Chaney, S. J., Komura, K., Roberts, B. J., \& McKee, S. (2000, March). Perspectives, problems, and practices in treating written error. Colloquium presented at International TESOL Convention, Vancouver, British Columbia, Canada.

Ferris, D. R., \& Helt, M. (2000, March). Was Truscott right? New evidence on the effects of error correction in L2 writing classes? Paper presented at the American Association of Applied Linguistics Conference, Vancouver, British Columbia, Canada.

Ferris, D. R., \& Helt, M. (2000). Was Truscott right? New evidence on the effects of error correction in L2 writing classes. Paper presented at the AAAL Conference, Vancouver, B.C.

Ferris, D. R., \& Roberts, B. (2001). Error feedback in L2 writing classes: How explicit does it need to be. Journal of Second Language Writing, 10, 161-184.

Ferris, D.R. (2002). Treatment of error in second language student writing. Ann Arbor: University of Michigan Press.

Ferris, D. R. (2003). Response to student writing: Implications for second language students. Mahwah, NJ: Lawrence Erlbaum Associates.

Frantzen, D. (1995). The effects of grammar supplementation on written accuracy in an intermediate Spanish content course. Modern Language Journal, 79, 329-344. 
George, H.V. (1972). Common errors in language learning. Rowley, Massachusetts.

Gue'nette, D. (2007). Is feedback pedagogically correct? Research design issues in studies of feedback on writing. Journal of Second Language Writing, 16, 40-53.

Harashima, H. (2006). An error analysis of the speech of an experienced Japanese learner of English. Retrieved from http:// www.kyoai.ac.jp/college/ronshuu/no-06/harashima.pdf

Hedgcock, J., \& Lefkowitz, N. (1994). Feedback on feedback: Assessing learner receptivity to teacher response in L2 composing. Journal of Second Language Writing, 3, 141-163.

Hyland, F. (2001). Providing effective support: Investigating feedback to distance language learners. Open Learning, 16(3), 233-247.

Kepner, C. G. (1991). An experiment in the relationship of types of written feedback to the development of second-language writing skills. Modern Language Journal, 75, 305- 313.

Khodabandeh, F. (2007). Analysis of students' errors: the case of headlines. The Asian ESP Journal, 3(1).

Komura, K. (1999). Student response to error correction in ESL classrooms. Unpublished master's thesis. Sacramento: California State University.

Krashen, S. D. (1982). Principles and practices in second language acquisition. Oxford: Pergamon Press.

Lado, R. (1964). Language teaching: a scientific approach. New York: McGraw-Hill.

Lalande, J. F., II (1982). Reducing composition errors: An experiment. Modern Language Journal, 66, 140- 149.

Lee, I. (2005). Error correction in the L2 writing classroom: What do students think? TESL Canada Journal, 22(2), $1-16$.

Lee, I. (2008). Student reactions to teacher feedback in two Hong Kong secondary classrooms. Journal of Second Language Writing (17), 144-164.

Lee, I. (2003). L2 writing teachers' perspectives, practices and problems regarding error feedback. Assessing Writing, 8, 216-237.

Leki, I. (1991). The preferences of ESL students for error correction in college-level writing classes. Foreign Language Annals, 24, 203-218.

Leki, I. (2006). "You cannot ignore": Graduate L2 students' experience of and response to written feedback practices within their disciplines. In K. Hyland \& F. Hyland (Eds.), Feedback in ESL writing: Contexts and issues. Cambridge: Cambridge University Press.

Leow, R.P., 1998. Toward operationalizing the process of attention in SLA: evidence for Tomlin and Villa's fine grained analysis of attention (1994). Applied Psycholinguistics, 19, 133-159.

Londono Vasquez ,D.A. (2007). Error Analysis. Retrieved October 21, 2008, from http:/?davilondono.blogspot.com

Muranoi, H., (2000). Focus on form through interaction enhancement: integrating formal instruction into a communicative task in EFL classrooms. Language Learning 50 (4), 617-673.

Nemser, W. (1971). Approximate systems of foreign language learners. IRAL, 9, 115- 123.

Oladejo, J. A. (1993). Error correction in ESL: Learners' preferences. TESL Canada Journal, 10(2), 71-89.

Polio, C., Fleck, C., \& Leder, N. (1998). “If only I had more time'”: ESL learners' changes in linguistic accuracy on essay revisions. Journal of Second Language Writing, 7, 43- 68.

Radecki, P., \& Swales, J. (1988). ESL student reaction to written comments on their written work. System, 16, $355-365$.

Rennie, C. (2000). Error feedback in ESL writing classes: What do students really want? Unpublished master's thesis.Sacramento: California State University.

Riazi, A. (1997). Acquiring disciplinary literacy: A socio-cognitive analysis of text production and learning among Iranian graduate students of education. Journal of Second Language Writing, 6(2), 105-137.

Richards, J. C. (1974). Error analysis: Perspectives on second language acquisition._London: Longman Group Ltd. Richards,j.c. (1974). A non contrastive approach to Error Analysis. English language teaching journal, 25, 204-229.

Robb, T., Ross, S., \& Shortreed, I. (1986). Salience of feedback on error and its effect on EFL writing quality. TESOL Quarterly, 20, 83-91. 
Saito, H. (1994). Teachers' practices and students' preferences for feedback on second language writing: A case study of adult ESL learners. TESL Canada Journal, 11, 46-70.

Schachter, J., \& Celce-Murcia,m. (1977). Some reservations concerning Error Analysis. TESOL Quarterly, 11. 441-451.

Schmidt, R., \& Frota, S., (1986). Developing basic conversational ability in a second language: a case study of an adult learner of Portuguese. In: Day, R., (Ed.), Talking to learn: Conversation in a second Language, Newbury House, Rowley, Mass, pp

Schmidt, R., (1990). The role of consciousness in second language learning. Applied Linguistics, 11, 129-158. Schmidt, R., (1994). Deconstructing consciousness in search of useful definitions for applied linguistics. AILA Review, 11, 11-26.

Schmidt, R., (2001). Attention. In: Robinson, P. (Ed.), Cognition and Second Language Instruction. Cambridge University Press, Cambridge, pp. 3-32.

.237-326.

Scott, V.M., (1989). An empirical study of explicit and implicit grammar teaching strategies in French. Modern Language Journal, 73, 14-22.

Scott, V.M., (1990). Explicit and implicit grammar teaching strategies: new empirical data. French Review, 63, 779-789.

Selinker, L. (1972). Interlanguage. IRAL, 10 (3), 219-243.

Semke, H. (1984). The effect of the red pen. Foreign Language Annals, 17, 195-202.

Sheppard, K. (1992). Two feedback types: Do they make a difference? RELC Journal, 23, 103- 110.

Truscott, J. (1996). The case against grammar correction in L2 writing classes. Language Learning, 46, 327-369.

Truscott, J. (1999). The case for " the case for grammar correction in L2 writing classes": A response to Ferris. Journal of Second Language Writing, 8, 111-122.

Truscott, J. (2007). The effect of error correction on learners' ability to write accurately. Journal of Second Language Writing, 16, 255-272.

Truscott, T. Yi-ping Hsu, A. (2008). Error correction, revision, and learning. Journal of Second Language Writing, 17, 292-305.

VanPatten, T. R. Dvorak, \& J. F. Lee (Eds.), Foreign language learning: A research perspective (pp. 92-107). Cambridge: Newbury House.

Table1. Interlingual errors

\begin{tabular}{|l|c|c|c|c|}
\hline Interlingual Errors & Frequency1 & Percentage1 & Frequency2 & Percentage2 \\
\hline Misuse of preposition & 25 & $19.6 \%$ & 10 & $13.7 \%$ \\
\hline Using double subject in relative clauses & 11 & $8.6 \%$ & 6 & $8.2 \%$ \\
\hline Farsi structure with English lexicon & 45 & $35.4 \%$ & 27 & $36.9 \%$ \\
\hline Misplacing adverbs of frequency in case of modal verbs & 5 & $3.9 \%$ & 1 & $1.36 \%$ \\
\hline Adjectives used after noun & 2 & $1.5 \%$ & 0 & $0 \%$ \\
\hline Omission of dummy "it" & 5 & $3.9 \%$ & 6 & $8.21 \%$ \\
\hline Omission of personal pronoun & 9 & $7 \%$ & 6 & $8.21 \%$ \\
\hline Omission of subjects & 18 & $14.1 \%$ & 12 & $16.43 \%$ \\
\hline Double negative & 5 & $3.9 \%$ & 2 & $2.73 \%$ \\
\hline Misuse of reciprocal verbs & 2 & $1.5 \%$ & 3 & $4.1 \%$ \\
\hline Total & 127 & $100 \%$ & 73 & $100 \%$ \\
\hline
\end{tabular}


Table 2. Intralingual errors

\begin{tabular}{|c|c|c|c|c|}
\hline Intralingual errors & Frequency1 & Percentage1 & Frequency2 & Percentage2 \\
\hline Addition of "The" & 14 & $4.32 \%$ & 17 & $6.2 \%$ \\
\hline Use of wrong tense & 14 & $4.32 \%$ & 16 & $5.83 \%$ \\
\hline A for An & 6 & $1.85 \%$ & 1 & $.36 \%$ \\
\hline Disagreement of subject and number & 21 & $6.48 \%$ & 15 & $5.47 \%$ \\
\hline Failure to attach $3^{\text {rd }}$ person "s" & 39 & $12 \%$ & 30 & $10.94 \%$ \\
\hline Failure to attach plural "s" & 71 & $21.9 \%$ & 63 & $23 \%$ \\
\hline Omitting "to" & 13 & $4 \%$ & 11 & $4 \%$ \\
\hline Misusing adverbs of quantity & 6 & $1.85 \%$ & 6 & $2.18 \%$ \\
\hline Misusing parts of speech & 34 & $10.5 \%$ & 29 & $10.58 \%$ \\
\hline Omission of articles & 52 & $16 \%$ & 48 & $17.51 \%$ \\
\hline Omitting to be verb & 12 & $3.7 \%$ & 8 & $2.91 \%$ \\
\hline Use of to be verb + simple form of verb & 6 & $1.85 \%$ & 4 & $1.45 \%$ \\
\hline To before object & 5 & $1.54 \%$ & 7 & $2.55 \%$ \\
\hline Use of do and does before main verb & 3 & $.92 \%$ & 0 & $0 \%$ \\
\hline Use of relative pronoun that for who & 8 & $2.46 \%$ & 3 & $1.09 \%$ \\
\hline Another for other & 8 & $2.46 \%$ & 7 & $2.55 \%$ \\
\hline Irregular plurals & 12 & $3.7 \%$ & 9 & $3.28 \%$ \\
\hline Total & 324 & $100 \%$ & 274 & $100 \%$ \\
\hline
\end{tabular}

